\title{
Gypsum domes and diapirs: common features in the Zechstein (Upper Permian) of Germany
}

\author{
Josef PAUL ${ }^{1, *}$ \\ 1 Abteilung Sedimentologie/Umweltgeologie, Geowissenschaftliches Zentrum der Universität Göttingen, Goldschmidt-Str. \\ 3, 37077 Göttingen, Germany
}

Paul, J., 2014. Gypsum domes and diapirs: common features in the Zechstein (Upper Permian) of Germany. Geological Quarterly, 58 (3): 521-530, doi: 10.7306/gq.1192

\begin{abstract}
The Upper Permian Zechstein Group contains three sulphate units (consisting of gypsum and/or anhydrite) of variable thickness. The upper parts of the gypsum units contain domes and diapirs protruding into the overlying strata. This gypsum diapirism is independent of salt diapirism. The best areas for observations and descriptions of this phenomenon are outcrops and mining districts around the Harz Mts. The lowermost gypsum member (Werra Anhydrite, A1) is overlain by dolomudstones and dolowackestones of the Main Dolomite (Ca2). The gypsum forms cupolas or elongate ridges, which are up to $50 \mathrm{~m}$ high, several kilometres long and may project through its roof. Above the ridges, the Ca2 roof is thinner or completely removed by slumping and sliding. The uplift of the gypsum started very early, before the carbonates were lithified. The ridges strike between 90 and $120^{\circ}$, most likely drawn out by tectonic forces. The Main Anhydrite (A3) around the Harz Mts. is overlain by the Younger Rock Salt (Na3) and behaves in the same manner. Large gypsum clasts (up to five metres across) in the salt around the diapirs indicate inter-penetration. Reasons for the uplift include high water contents in the gypsum, additional release of water by the conversion of gypsum to anhydrite and, last but not least, bouyancy of the light gypsum mud against compact rock salt or semi-lithified carbonates.
\end{abstract}

Key words: gypsum diapirism, Zechstein, Werra Anhydrite, Leine Anhydrite, Germany.

\section{INTRODUCTION}

The Upper Permian Zechstein deposits were deposited in a nearly closed inland sea that was structured by palaeohighs into sub-basins. The main basin extended from England to Poland (Peryt et al., 2010a). The Zechstein sequence, up to a few kilometres thick, consists of classical evaporite cycles that form the framework of the stratigraphy (Richter-Bernburg, 1955; Table 1). The Zechstein cycles start with marine carbonates, followed by sulphates, rock salt and then potassium salts. In Germany, there are six cycles starting with marine mudstones or carbonates and ending with rock salt or potassium salts; the seventh cycle, which corresponds to the Fulda Formation, consists only of terrestrial strata.

Precipitation of rock salt was mainly restricted to the main basin and lagoons at the margin of the basin, whereas towards palaeohighs the thickness of the anhydrite deposits increases (e.g., Richter-Bernburg, 1985). The anhydrites are composed of alternating laminated, well-bedded, massive and chickenwire sulphate (e.g., Langbein, 1987 with references therein; cf. Peryt et al., 2010b). The Werra Anhydrite Member (A1) in Germany, the anhydrite of the first evaporite cycle, is about $40 \mathrm{~m}$

\section{*E-mail: renate.paul@web.de}

Received: Receiced: June 6, 2014; accepted: August 30, 2014; first published online: September 16, 2014 thick in basinal areas and up to $350 \mathrm{~m}$ thick on the fringes of palaeohighs (Table 1); the same thickness pattern is characteristic of other areas of the Zechstein 1 basin (e.g., Peryt, 1994). The Stassfurt Anhydrite Member, the second cycle anhydrite (A2), is only several metres thick in the basin, whereas in slope positions its thickness reaches $100 \mathrm{~m}$. The thickness of the Leine Anhydrite Member (A3) is more even because the earlier Zechstein formations, and in particular the Zechstein 2 salts, had levelled the former morphology of basins and highs. The thickness of $\mathrm{A} 3$ varies between 25 and $60 \mathrm{~m}$.

Zechstein salt units are famous for their extensive and spectacular salt diapirism. In turn, doming and diapirism of gypsum deposits are not well-known and are less spectacular. This paper describes some field examples of the extraordinary mobility of gypsum in forming domes and diapirs during very early stages of diagenesis.

\section{PREVIOUS STUDY - "CLIFFS" OF THE LEINE ANHYDRITE (A3)}

During mining of potassium and rock salt in Sachsen-Anhalt near Stassfurt in the second part of the 19th century, geologists observed and described irregular thicknesses of the Leine Anhydrite (A3). Everding (1907) indicated that in this area the thickness of $A 3$ varies between 40 and $90 \mathrm{~m}$. A detailed description of this phenomenon was given by Fulda (1929). He termed 
Table 1

Simplified stratigraphy and thickness of lower Zechstein strata around the Harz Mts.

\begin{tabular}{|l|c|c|c|}
\hline Formations & $\begin{array}{c}\text { Members } \\
\text { Symbols }\end{array}$ & Basin [m] & $\begin{array}{c}\text { High } \\
{[\mathrm{m}]}\end{array}$ \\
\hline \multirow{4}{*}{ Leine Fm. } & $\mathrm{Na} 3$ & $100-150$ & 0 \\
\cline { 2 - 4 } & $\mathrm{A} 3$ & 35 & $50-60$ \\
\cline { 2 - 4 } & $\mathrm{Ca} 3$ & 0 & $0-20$ \\
\cline { 2 - 4 } & $\mathrm{T} 3$ & 5 & $1-10$ \\
\hline \multirow{4}{*}{ Stassfurt Fm. } & $\mathrm{Na} 2$ & $200-500$ & 0 \\
\cline { 2 - 4 } & $\mathrm{A} 2$ & $2-3$ & $0-70$ \\
\cline { 2 - 4 } & $\mathrm{Ca} 2$ & $3-5$ & -100 \\
\hline \multirow{4}{*}{ Werra Fm. } & $\mathrm{Na} 1$ & $0-8$ & 0 \\
\cline { 2 - 4 } & $\mathrm{A} 1$ & $40-50$ & $0-300$ \\
\cline { 2 - 4 } & $\mathrm{Ca} 1$ & $5-8$ & $0-80$ \\
\cline { 2 - 4 } & $\mathrm{T} 1$ & 0.5 & $0-2$ \\
\hline
\end{tabular}

Symbols after Richter-Bernburg (1955): T - claystone, $\mathrm{Ca}$ - carbonate, $\mathrm{A}$ - anhydrite, $\mathrm{Na}$ - rock salt; basin data refer to the Subhercynian Basin north of the Harz Mts. and palaeohigh data to the Eichsfeld -Altmark High; data mainly from Hemmann (1972) and Paul (1993)

the elevations "anhydrite cliffs" and differentiated between small features, several metres high, and large ones, up to $50 \mathrm{~m}$ high. Hemmann (1968,

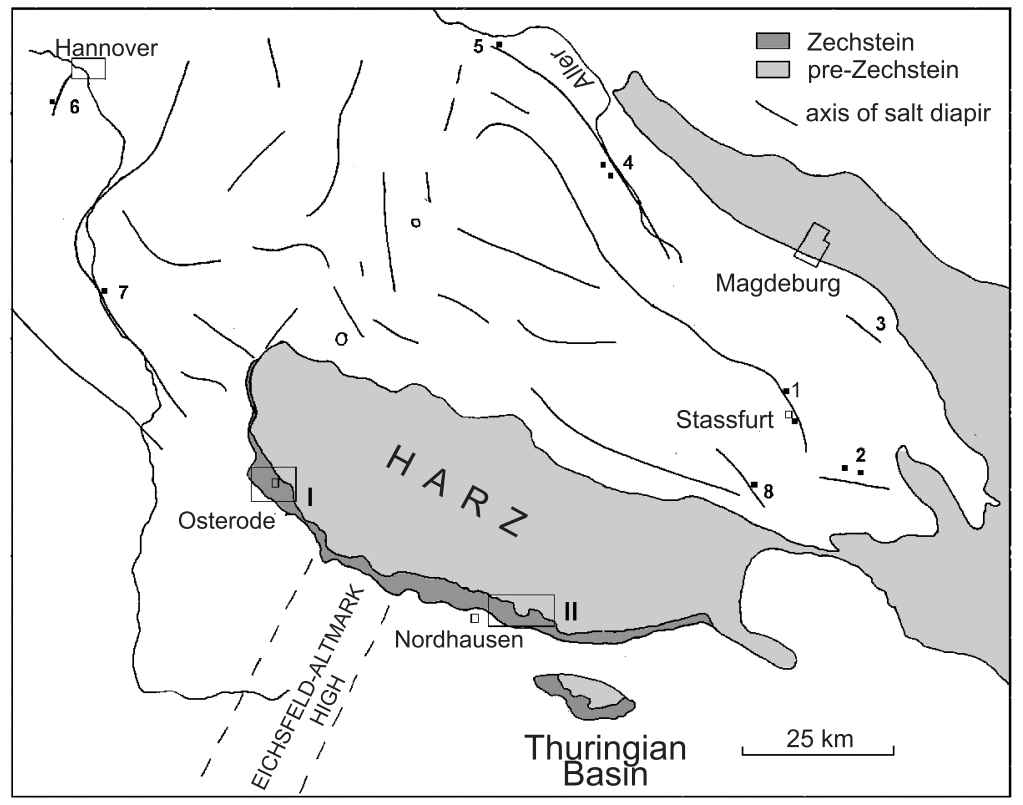

Fig. 2 Sketch-map of the Subhercynian Basin and the Harz region with sites where gypsum domes and diapirs are observed

1 - Stassfurt, 2 - Bernburg, 3 - Schönebeck, 4 - upper Aller River valley, 5 Subhercynian Basin, 6 - Calvörde block, 7 - Hannover, 8 - middle Leine River valley, I - Osterode region (shown in Fig. 4), II - Nordhausen region (shown in Fig. 15)
1972) described the domes in detail and summarized the various theories of their genesis. His observations indicated that the A3 domes in the Stassfurt area are up to $50 \mathrm{~m}$ high, 15 to $120 \mathrm{~m}$ across and can be traced horizontally over distances of several hundred metres (Fig. 1). Very often their upper part is expanded and has a pear-like shape with steep flanks. Thin, but long protrusions of anhydrite extend along bedding planes into the neighbouring rock salt. Around these domes the thickness of $A 3$ is reduced to $16 \mathrm{~m}$ or less (Fig. 1).

Hemmann (1972) noticed that the anhydrite domes - especially near their tops - contain numerous salt crystals for up to a third of their total volume, and in turn the rock salt above the anhydrite domes contains more anhydrite crystals than in areas where no domes are present. He also remarked that only the upper part of $\mathrm{A} 3$ is involved in the formation of the dome (Fig. 2).

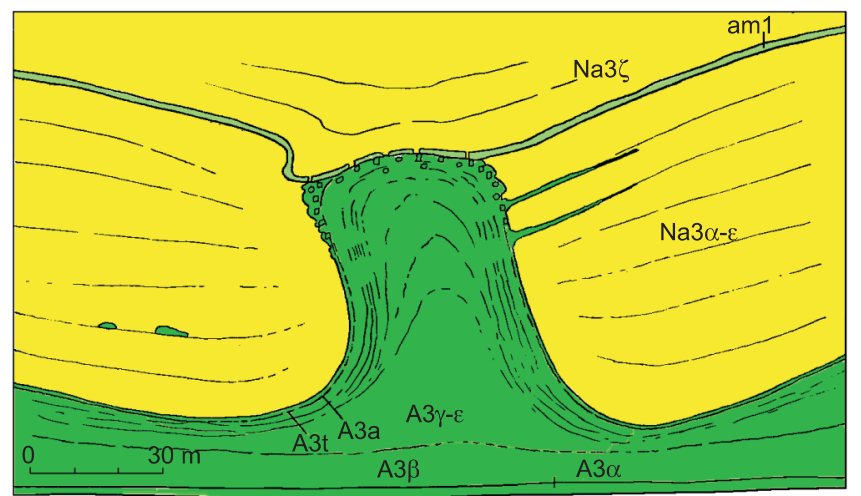

Fig. 1. Idealized cross-section of an A3 gypsum diapir

Modified after Hemmann (1972); for abbreviations and thicknesses of stratigraphic units see Table 2
Schachl (1991) made similar observations in a mine in the Allertal district.

According to Jung et al. (1969) and Hemmann (1972), the A3 profile shows compositional and textural differences which are used for its detailed stratigraphic subdivision (Table 2). In the Stassfurt area, the lowermost subunit (dark grey A3 $\alpha$, cf. Fig. 1) is only up to three metres thick, has a high carbonate content and was deposited in a sabkha environment. The development of other subunits of $A 3$ varies between chicken-wire and well-bedded anhydrite. But, these horizons are not consistent in the Zechstein basin and may change from region to region (but see Reimann and Richter, 1991). The uplift of the anhydrite is terminated by a series of anhydrite (am1) layers (Fig. 1). Near the domes there are often large anhydrite blocks or clasts (Fig. 1). The importance of this observation is discussed below in the chapter "Interpretation and Discussion".

In the 20th century, such remarkable anhydrite domes were also found in areas where mining of the Leine Salt (Na3) took place: in the middle Leine River valley (Renner, 1914); in the area around Hannover (Kosmahl 1967, 1969; Struensee, 1981); in the Subhercynian region north of the Harz Mts. (Behr, 1960; Hemmann, 1968); in the upper Aller River valley (Zwanzig, 1928; Schachl, 1991) and the Calvörde block (Fig. 2). Behr (1960) and Hemmann (1972) reported anhydrite domes similar to those occurring in A3 - from the Stassfurt Anhydrite (A2) in the salt mines south of the Harz Mts. In some areas Hemmann (1972) determined the preferential directions of these elongate gypsum domes.

As salt near the surface is dissolved in the humid climate of central Europe, gypsum domes can only observed at subsurface in areas where salt is mined. However, during the last fifty years, most of these mines have been closed and are not accessible. 
Table 2

Stratigraphy, thickness and characteristics of the Leine Anhydrite (A3) in the Subhercynian Basin

\begin{tabular}{|l|c|c|}
\hline \multicolumn{1}{|c|}{ Stratigraphy } & $\begin{array}{c}\text { Thickness } \\
{[\mathrm{m}]}\end{array}$ & Characteristics \\
\hline Na3 zeta-eta & 30 & with anhydrite layers \\
\hline am1 & & intercalation of anhydrite in the salt \\
\hline Na3 alpha-epsilon & 50 & rock salt \\
\hline A3a Anhydritschale & $>0.5$ & thin anhydrite layer \\
\hline A3t black clay layer & $0.0-0.1$ & residue of dissolved evaporites \\
\hline A3 epsilon & $0-30$ & very few carbonates and clay \\
\hline A3 delta & $1-9$ & middle grey, bedded \\
\hline A3 gamma & $2-8$ & chicken wire anhydrite \\
\hline A3 beta & $7-12$ & light grey, less carbonate content \\
\hline A3 alpha & $1-3$ & dark grey, high carbonate content \\
\hline
\end{tabular}

\section{DOMES AND DIAPIRS OF THE WERRA ANHYDRITE (A1)}

Another type of gypsum doming and diapirism from central Germany, at the south-west margin of the Harz Mts., was described by Paul (1987) and Williams-Stroud and Paul (1997). Here, the gypsum is not overlain by rock salt, but by carbonates: the Stassfurt Carbonate (Table 1). A broad belt of Zechstein strata crops out south of the Variscan Harz Mts. A more or less NE-SW striking palaeohigh, the Eichsfeld-Altmark High $(\mathrm{EAH})$, crosses the Harz Mts. (Figs. 2 and 3). After the Late Cretaceous, the area was uplifted and the Mesozoic cover was eroded.

As a consequence of this configuration, a cross-section along the southern Zechstein belt of the Harz Mts. runs from the North German Zechstein basin (main basin) to the top of the $\mathrm{EAH}$ and down to the Thuringian Basin (Figs. 2 and 3). At the north-west foot of the EAH, the Werra Anhydrite (A1) is about $50 \mathrm{~m}$ thick. Towards the $E A H$, the thickness of $A 1$ increases up to $300 \mathrm{~m}$, but is missing at the top. No rock salt of the Werra Formation (Na1) was precipitated on top of the EAH (cf. Fig. 3). In the field, the boundary between $\mathrm{A} 1$ and the overlying Stassfurt Carbonate (Ca2) is often poorly visible due to the cover of Quaternary deposits, however, there are numerous natural cliffs and large quarries for observations and measurements (Fig. 4).
Borchert and Baier (1953) demonstrated that in the Zechstein basin all thick marine sulphate horizons were originally precipitated as gypsum. Kosmahl (1969) confirmed this for $\mathrm{A} 3$ as he found pseudomorphs of swallow-tail crystals which are typical of gypsum origin.

Later, during burial, the gypsum was converted to anhydrite due to the increased load and thus pressure of the overlying Zechstein and Triassic strata (Langbein, 1987). This conversion process is discussed below. Uplift of central Europe started during the Cretaceous. South and west of the Harz Mts. more than $1000 \mathrm{~m}$ of Mesozoic rocks have been eroded, reducing the burden on the anhydrite and consequently the pressure. Moreover, during the uplift the anhydrite came in to contact with groundwater. As a result of this process, the anhydrite near the surface was rehydrated. The texture of crystals has been more or less completely changed by the regypsification, but macrostructures, such as bedding planes, clay flasers and chicken wire fabrics, are preserved (Reimann, 1991).

Gypsum doming and diapirism in A1 is demonstrated by three examples located near Osterode at the western margin of the Harz Mts. (Fig. 4): Schimpf Quarry, Hellenberg Quarry and Rötzel. The thickness of A1 in the Osterode area is about 100-200 m. The detailed mapping of a large area near Nordhausen at the southern margin of the Harz Mts. yielded additional information about the gypsum doming diapirism (Fig. 2).

\section{SCHIMPF QUARRY}

West of Osterode, there are several gypsum quarries with a combined length of several kilometres along the escarpment of the Oder River. These quarries allow for a two-dimensional, often also three-dimensional, view of the upper A1 and its contact with the overlying Ca2 (Fig. 5). The boundary of $A 1$ with Ca2 is wavy. Formerly it was supposed that this wavy surface is the result of recent partial leaching and underground erosion of the gypsum, or that it was overlooked (cf. Herrmann and Richter-Bernburg, 1955; Herrmann, 1957).

Measurements of the dip of gypsum bedding planes showed that they are parallel to the outline of the domes (Fig. 5). In some cases the entire shape of diapirs can be reconstructed. There are round cupolas with a horizontal top and steep to vertical slopes that become shallower downwards (Fig. 6).

The upper part (5-10 m thick) of the gypsum unit is laminated. My observations and the information given by the quarry manager (S. Brandt) indicate that this part of $A 1$ is very pure.

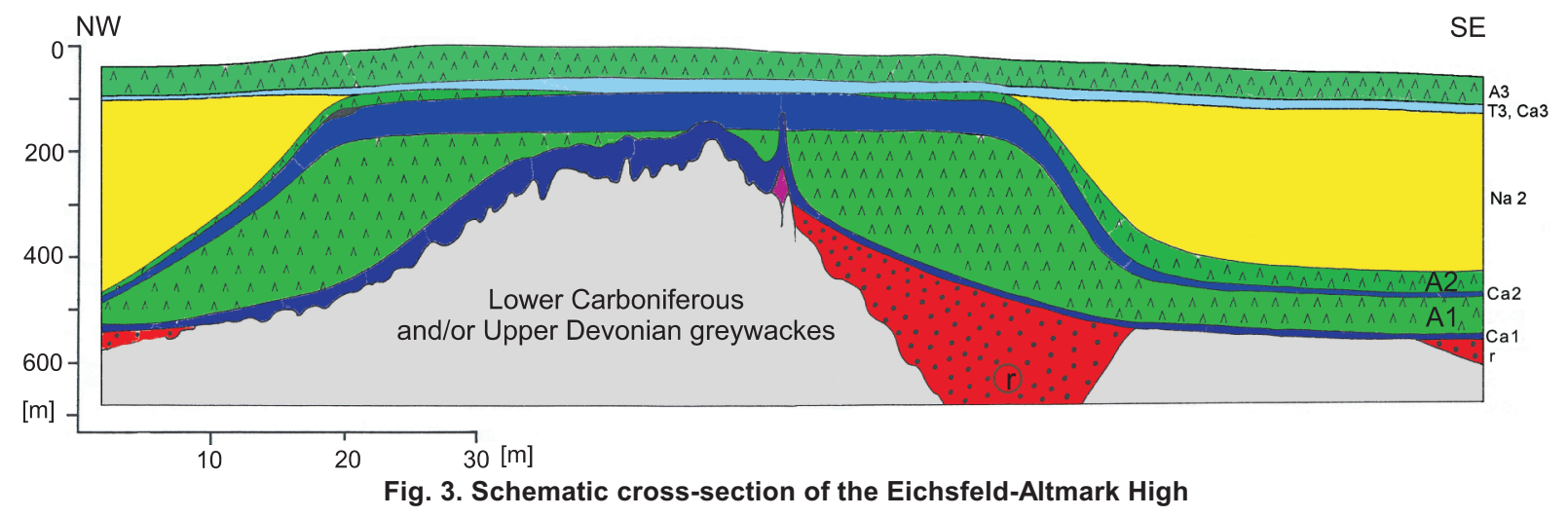

r - Rotliegend (Lower Permian), Ca1 - Werra Carbonate, A1 - Werra Anhydrite, Ca2 - Stassfurt Carbonate, A2 - Stassfurt Anhydrite, Na2 - Stassfurt Salt, T3 - Leine Clay, Ca3 - Leine Carbonate, A3 - Leine Anhydrite 


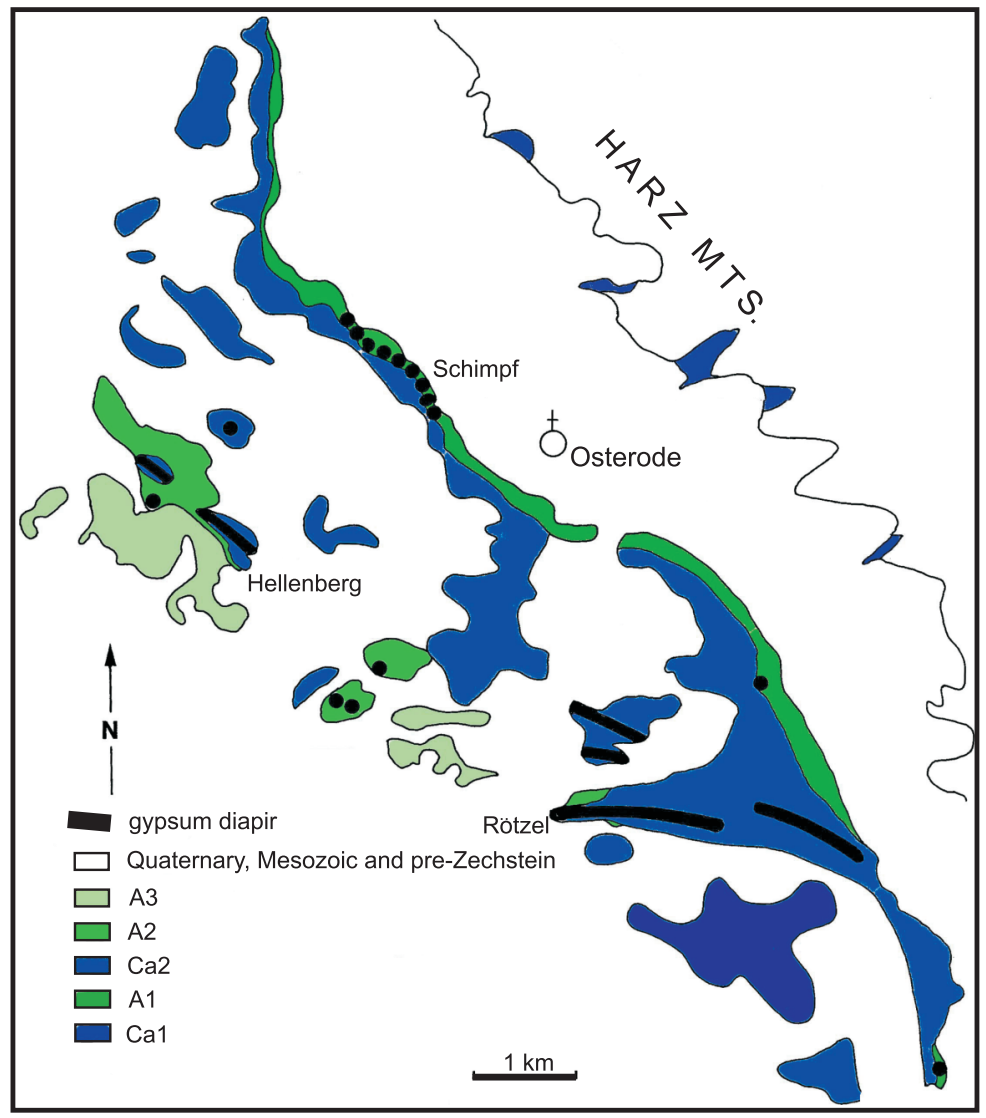

Fig. 4 Sketch-map of the Osterode area and occurrence of gypsum domes and diapirs

The abbreviations of stratigraphic units are explained in Figure 3

axis is marked by the highest position of the underlying gypsum (Fig. 9). It can be traced throughout the quarry, and strikes about $130^{\circ}$ (Fig. 10). Slump directions are perpendicular to this direction. Bedding planes of $\mathrm{Ca} 2$ dip at $20-40^{\circ}$ at right angles to the fold axis (Figs. 8 and 10). The northern part of the quarry is dominated by folding (Fig. 11A). At the fold axes, dolomite beds are brecciated. Sliding is the prevailing process at the western and southern parts of the quarry. Carbonate blocks have slid downslope. Slickensides are uneven, but always perpendicular to the main axis (Fig. 11B). There is no secondary calcite that would indicate deformation in a solid state at the slickensides. The temporal succession of events can be reconstructed in some cases (Fig. 11B); slickensiding took place after sliding. All this deformation took place in a semi-lithified state of the $\mathrm{Ca} 2$ carbonate.

At some places slickensides have nearly horizontal striae, indicating that parts of the Ca2 moved away from the rising gypsum ridge. It seems that thin-bedded dolomudstones are slumped whereas thick beds reacted by folding and sliding with curved slickensides (Fig. 11A). At the south side of the quarry, there are thin layers or lenses of black coarse crystalline dolomite on top of $\mathrm{Ca} 2$, a peculiarity in the Zechstein. The crystal size of the dolomite is up to five millimetres. In the Osterode area, these crystals have been found in several exposures always at the top of $\mathrm{Ca} 2$. These crystals were called by geologists of the 19th century, on account of their black colour, "Anthrakonit". This means that the complete $\mathrm{Ca} 2$ horizon is exposed in the quarry. Therefore, the total thickness of $\mathrm{Ca} 2$ in the quarry can be estimated as less than 10 metres. The normal thickness of $\mathrm{Ca} 2$ in the area amounts to $40 \mathrm{~m}$,

Ten metres below the diapirs the gypsum is horizontally bedded, bedding planes show a larger detachment and some sections show flaser structure. There are selenite horizons in the lower part of $A 1$ whereas no selenite has been found within the diapirs (Fig. 7).

\section{HELLENBERG QUARRY}

The relation of the overlying $\mathrm{Ca} 2$ to the rising gypsum masses can best be seen in a disused quarry at Hellenberg, $2 \mathrm{~km}$ away from Osterode (Fig. 8) where an elongate ridge consisting of quarried $\mathrm{Ca} 2$ rocks is exposed. The underlying $\mathrm{A} 1$ is also exposed in some places. Ca2 consists of well-bedded dark grey dolomudstones and dolowackestones; the beds are a few centimetres to half a metre thick. Ca2 is heavily deformed by slumping, sliding, folding and faulting (Figs. 8-11). The main fold as in the quarry of Ührde, about two km away from the Hellenberg Quarry; thus more than half of the thickness of $\mathrm{Ca} 2$ typical of the area was removed from the ridge by slumping and sliding or was not deposited.

\section{RÖTZEL HILL}

The Rötzel is an elongate ridge south-west of Osterode (Figs. 4 and 12-14). The ridge is about $200 \mathrm{~m}$ wide at the base, but only a few metres wide at the top. It is about $30 \mathrm{~m}$ high and can be traced morphologically over a distance of two kilometres.

Several small disused quarries give insight into the internal structure of the ridge (Fig. 13). The core of this ridge consists of A1 gypsum which is overlain by $\mathrm{Ca} 2$ dolomudstones. At the slope of the ridge, A2 is exposed in places. At the top A1 has

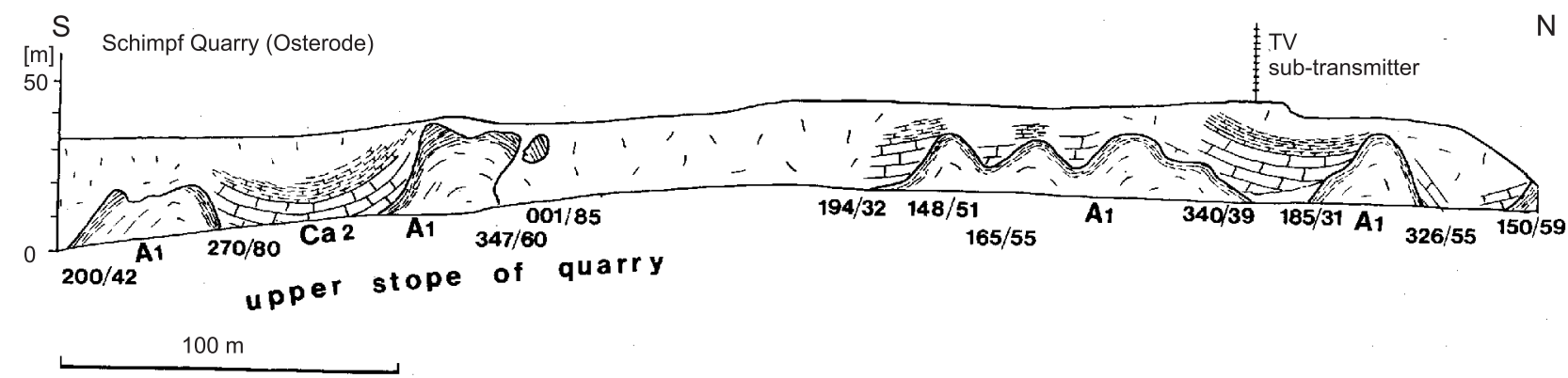

Fig. 5. A1 gypsum diapirs at Schimpf Quarry (after Paul, 1987) 


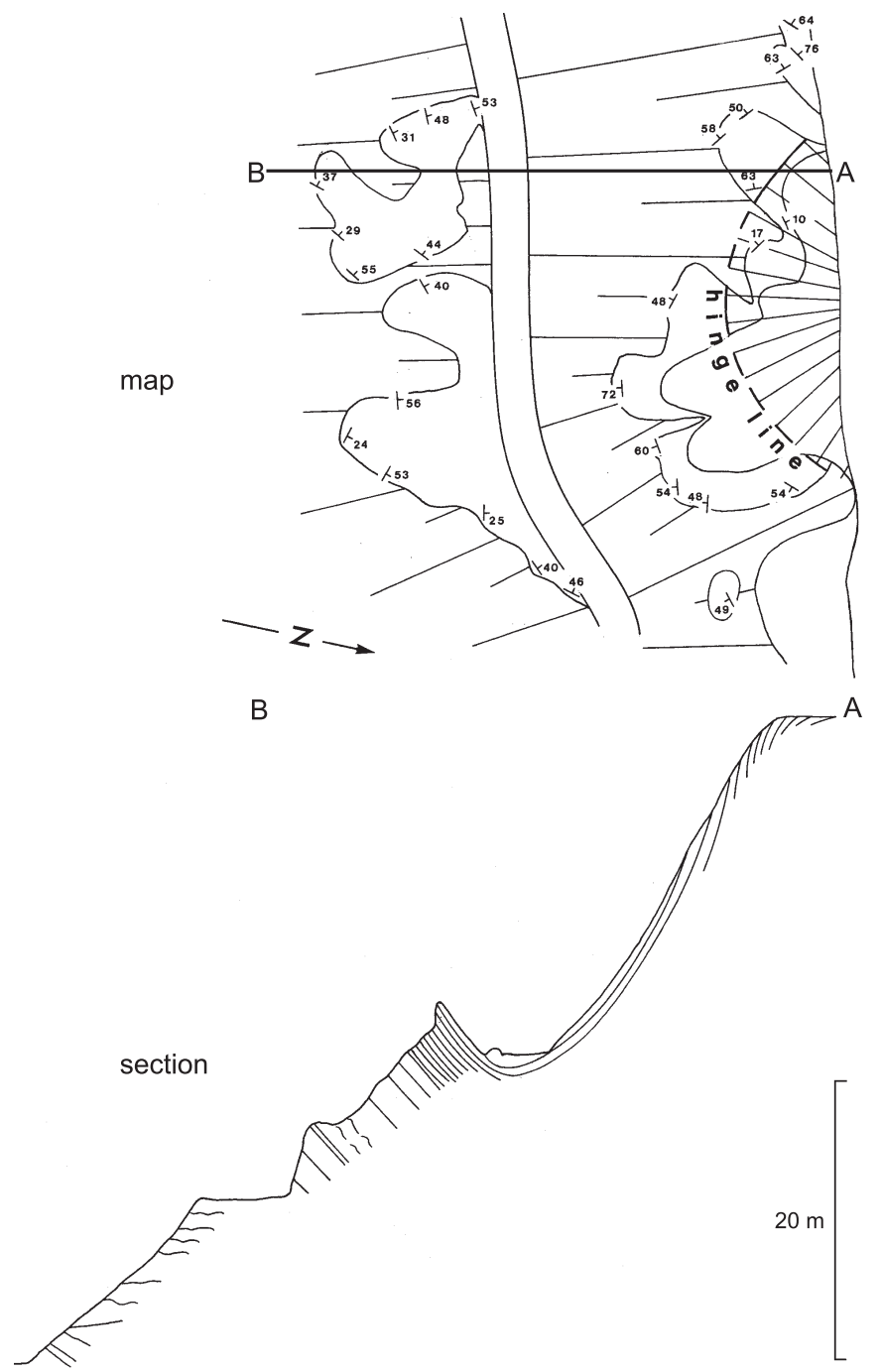

Fig. 6. Map and section of a gypsum dome at Schimpf Quarry

A-B - position of the section; the scale is for horizontal and vertical directions; notice that the left part of the section shows interpreted part located outside map shown in the upper part of the figure

pierced its $\mathrm{Ca} 2$ roof and is in contact with $\mathrm{A} 2$. Near the contact with gypsum, dolomite occurs as scattered unrounded clasts some millimetres to some centimetres across. In some places gypsum fills small cavities within this brecciated dolomite (Fig. 14). North of the top there is a second protrusion of $A 1$ that does not reach A2 (Fig. 13). Near the quarry base a small ridge of gypsum, vertically foliated parallel to the direction of the gypsum anticline, is exposed.

\section{NORDHAUSEN AREA}

South of the Harz Mts. at Nordhausen (Fig. 2), the cover of Quaternary deposits above the Zechstein is thinner than in the other areas around the Harz Mts. Paul et al. (1998) mapped an area of about $40 \mathrm{~km}^{2}$ in the scale of $1: 10,000$, especially focusing on the sulphate horizons of the Zechstein (Fig. 15). This mapping yielded detailed information about the deformation of the sulphate. It was found that all over the mapped area, A1 was completely folded as in a fold belt. This was neither expected nor observed before, as in non-Alpine Central Europe the post-Variscan strata are a flat-lying layer-cake. Narrow and acuate anticlines are in contrast to broad and gentle synclines.

The types of deformation are roughly the same as in the Osterode region. The dip of the beds varies between vertical and horizontal. Axes of individual anticlines and synclines can be traced over distances of several kilometres. Anticlines are about 0.5 to $1.5 \mathrm{~km}$ away from each other. Long anticlines prevail in contrast to round cupolas. All the folds strike more or less in the same direction: about $120^{\circ}$.

\section{OTHER AREAS OF GYPSUM DOMES AND DIAPIRS}

At the eastern border of the Rheinisches Schiefergebirge near Adorf, gypsum of the Werra Anhydrite (A1) has been extracted since late medieval times from an underground pit which is now closed. Due to its location near the palaeocoast-line of the Zechstein sea, a few clay layers are intercalated with the gypsum; typically, there are three gypsum beds. The total thickness of $A 1$ is about $40 \mathrm{~m}$ (Kulick, 1987). Finkenwirth (1982) described, from the lowermost gypsum bed, round gypsum domes $10-20 \mathrm{~m}$ in diameter and $10 \mathrm{~m}$ in height. Slopes of the domes are up to $45^{\circ}$ steep. The clay beds covering the gypsum are also upwarped and deformed. There is no information about the form of the domes and their preferential direction.

Schachl (1954) reported, from rock salt mines of the Middle Triassic Muschelkalk in south-west Germany, that the anhydrite at the base of the rock salt forms domes several metres high; normally, the anhydrite is only several metres thick. The thin layer of salt clay between the anhydrite and the rock salt is partly involved in doming, partly missing on top of the high.

Outside the Central European Basin, gypsum diapirs were described from the Triassic in the Betic Cordillera in southern Spain by Calaforra and Pulido-Bosch (1999).

\section{INTERPRETATION AND DISCUSSION}

Gypsum doming and diapirism are quite common features in the Zechstein around the Harz Mts. Former interpretations of these features are quite different: Fulda (1929) explained the A3 cliffs by a primary rise of precipitation due to an increased brine flow in convection cells; Weber (1931) and Richter (1934) thought that the A3 domes were included in the uplift of the rock salt - most workers agreed with this opinion and drew in their diagrams and drafts faults between gypsum and rock salt (cf. Seidl, 1914; Fleischer, 1960). This interpretation was also adopted in text-books at the time (Lotze, 1938; Borchert, 1959). Richter-Bernburg (1985) described these "cliffs" as problematic structures of partly tectonic origin and partly synsedimentary precipitations. Langbein (1987) cited Hemmann (1972) and concluded that the cliffs "remain especially problematic". 


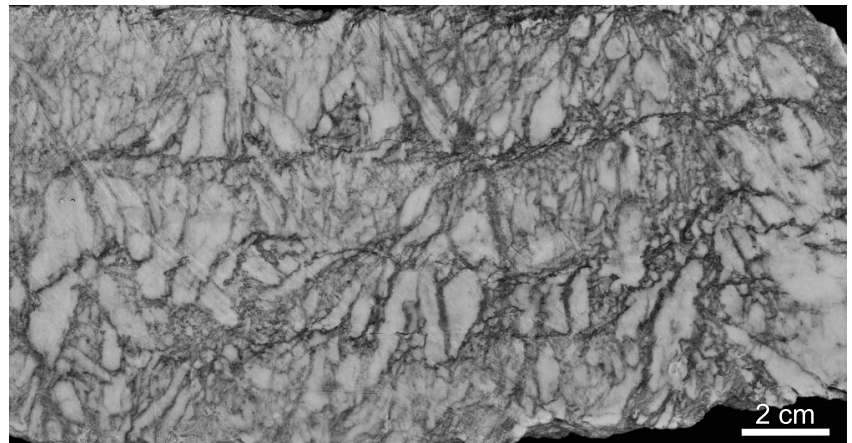

Fig. 7. Bottom-grown selenite crystals (Schimpf Quarry; A1)

Width of the photo $-20 \mathrm{~cm}$ (photo T. Paul)

In contrast to these opinions, Hemmann (1972) realized that gypsum diapirism is independent of salt diapirism. He also noticed that only the upper parts of A3 were included in the movement of the sulphate. From the high amount of rock salt crystals within the anhydrite domes and the high percentage of gypsum within the rock salt above the domes, he concluded that the sulphate at the time of uplift was still gypsum, highly mobile and containing a large volume of water. Although Hemmann (1972) and Schachl (1991) did not use the term diapir - mainly for linguistic reasons, they used the German word "Klippe" meaning "cliff" - it is clear that large anhydrite clasts of up to five metres across occurring within the rock salt adjacent to the domes prove that the surface of the sulphate penetrated the salt roof and parts of the sulphate broke off and slid away from the diapir (Fig. 1). These processes occurred before the gypsum was converted to anhydrite. Anhydrite is brittle, not ductile, and not mobile like rock salt.

The observations of the $\mathrm{A} 1$ domes and diapirs below the Ca2 dolomites by Paul (1987) and Williams-Stroud and Paul (1997) enlarged the knowledge of gypsum diapirism in other gypsum horizons. In the Hellenberg Quarry, the rise of the underlying gypsum at the main axis caused slumping, sliding, folding and slickensides of the overlying dolomite (Ca2).

My observations confirm Hemmann's (1972) description but the interpretation differs in several aspects. Hemmann (1972) thought that gypsum diapirism is triggered by water liberated due to the conversion of gypsum to anhydrite. After Borchert and Baier (1953) it was thought that about $0.5 \mathrm{~m}^{3}$ of water is dis-

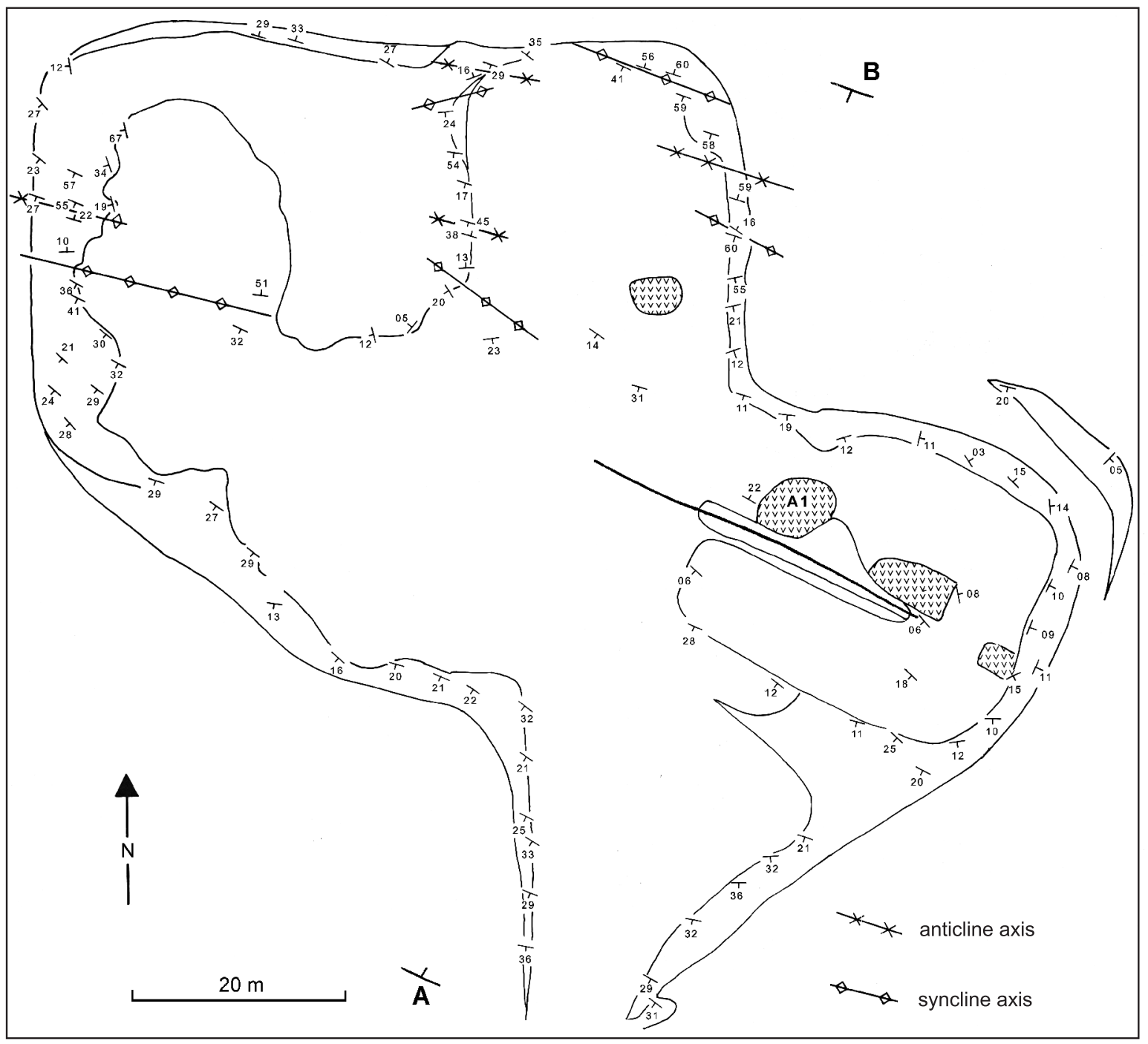

Fig. 8. Sketch-map of Hellenberg Quarry, west of Osterode

Direction and dip of Staßfurt Carbonate (Ca2) beds; A1 - Werra Anhydrite; the interior of the quarry is covered with rubble; A-B - location of cross-section shown in Figure 9; thick line - position of main axis 


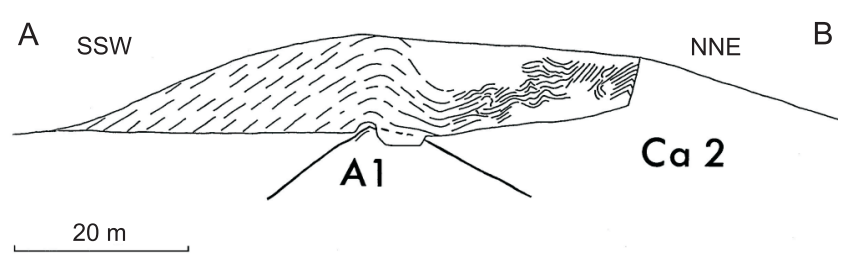

Fig. 9. Schematic cross-section of the Hellenberg Quarry along the A-B line shown in Figure 8

Thin lines indicate bedding planes; the thick line represents the boundary of dolomite (Ca2) and underlying gypsum (A1)

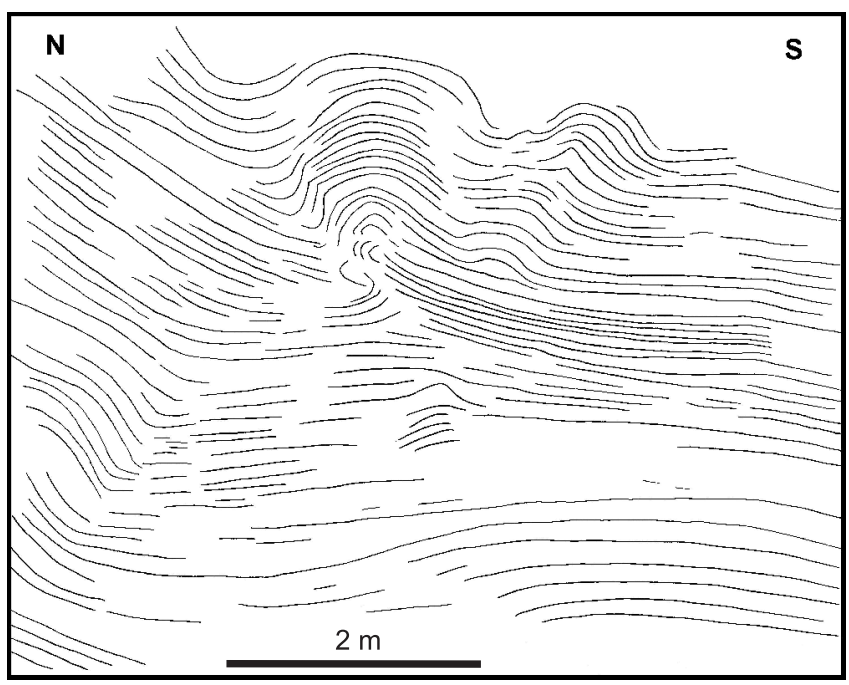

Fig. 10. Slump structures at the Hellenberg Quarry

The drawing-lines are bedding planes of $\mathrm{Ca} 2$; drawing after a photo

charged from $1 \mathrm{~m}^{3}$ of gypsum. The detailed conditions of the conversion are still under discussion (Braitsch, 1962; Hardie, 1967; Langbein, 1968, 1987; Langbein et al., 1982; Warren, 1999). The depth at which conversion takes place depends on temperature, geothermal gradient, lithostatic pressure and the types and concentrations of pore brines. Most likely, these processes took place at a depth of about one hundred metres (Marsal, 1952); for Zechstein, Langbein (1987) assumed that the minimum depth was $100 \mathrm{~m}$.

The upper part of the gypsum bed which is included in the diapirism movements differs in terms of structure and composition from the lower part. It is assumed that the upper parts of A1 and $\mathrm{A} 3$ had relatively high contents of pore water because the original deposit was gypsum mud in contrast to the lower part which consisted - at least partly - of bottom-grown gypsum crystals (cf., e.g., Langbein, 1987; Denison and Peryt, 2009). In both $\mathrm{A} 1$ and $\mathrm{A} 3$ the anhydrite is very pure and had most likely been precipitated from highly saline waters, and the upper parts of original gypsum units were precipitated at higher salinities than their lower parts. The salinity of the pore water influences the conversion of gypsum to anhydrite (e.g., Langbein, 1987). The mobile parts of $\mathrm{A} 1$ and $\mathrm{A} 3$ were at the top of the units, and it is characteristic that in all examples only the upper part of the original gypsum unit was involved in doming and diapirism.

The gypsum domes and diapirs around the Harz Mts. and elsewhere are relatively small in size in comparison to salt diapirs. It can be assumed that they could get larger and rise higher, if the amount of mobile gypsum was larger or the overburden was higher. Another factor which might influence the size and height of the domes and diapirs was the bulk of escaping water, pore water and water produced by the conversion of gypsum to anhydrite.

\section{ORIENTATION OF GYPSUM RIDGES}

In the Nordhausen area there occur round cupolas, though elongate ridges or anticlines prevail (Fig. 15). In the Osterode area the A1 diapirs strike between 90 and $120^{\circ}$; in the Nordhausen area they are strictly about $120^{\circ}$ (Fig. 15). The A3 diapirs north of the Harz Mts. strike in various directions: Hemmann (1972) reported strikes for the Bernburg mining district being mainly $110-150^{\circ}$, but also $20-50^{\circ}$; in the Stassfurt district they are about $50^{\circ}$; in the Aller River valley about 140 and $50^{\circ}$. It seems that the $\mathrm{A} 3$ diapirs strike parallel and normal to the direction of the salt diapirs, but these observations were made on gypsum diapirs located on the slopes of large salt diapirs, and therefore their orientation may have been changed.
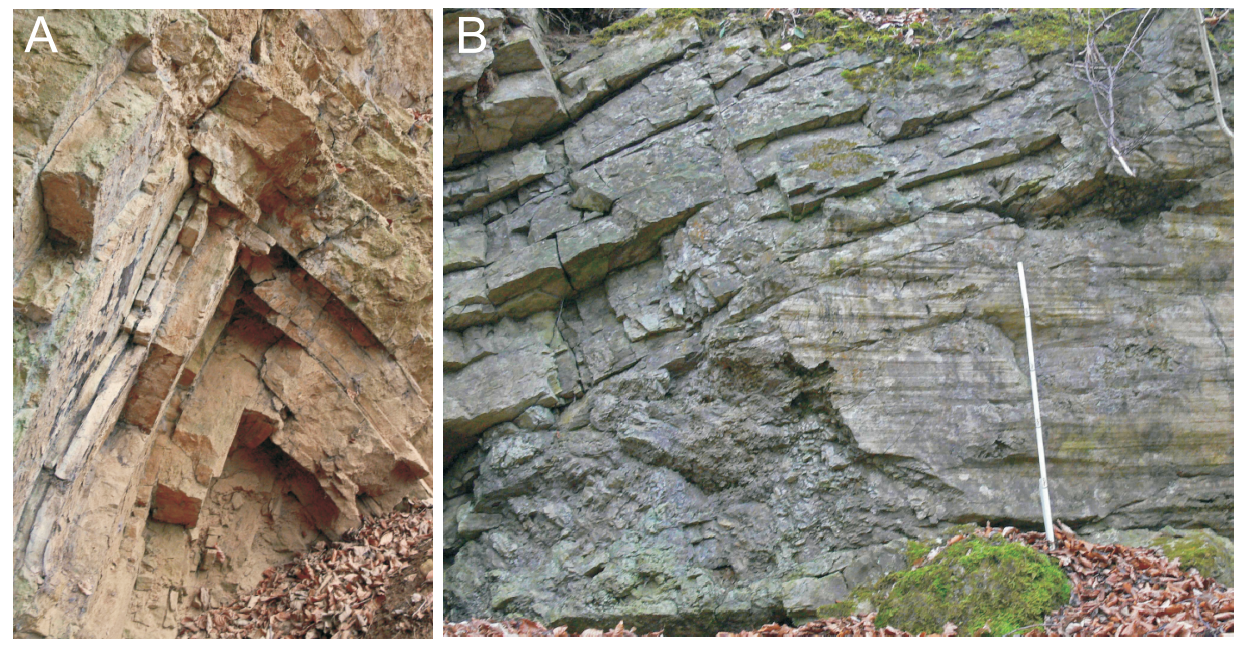

Fig. 11. Hellenberg Quarry

A - folds in Ca2 at the Hellenberg Quarry (breadth $-2 \mathrm{~m}$ );

B - horizontal slickensides are younger than sliding structures; length of the rule is $1 \mathrm{~m}$ 


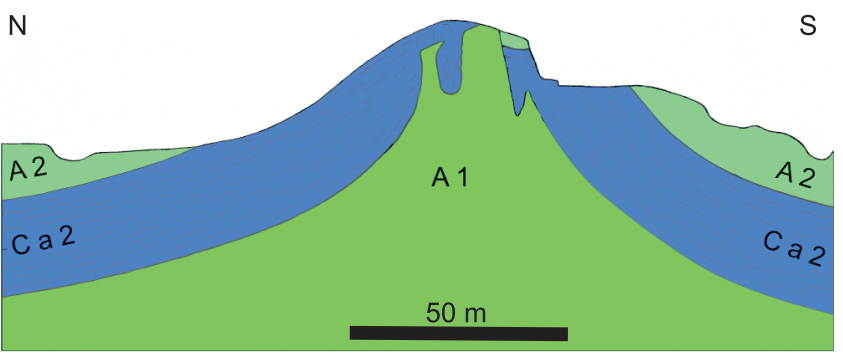

Fig. 12. Simplified cross-section of the Rötzel diapir, now a Nature Reserve

A1 - Werra Anhydrite, Ca2 - Stassfurt Carbonate, A2 - Stassfurt Anhydrite

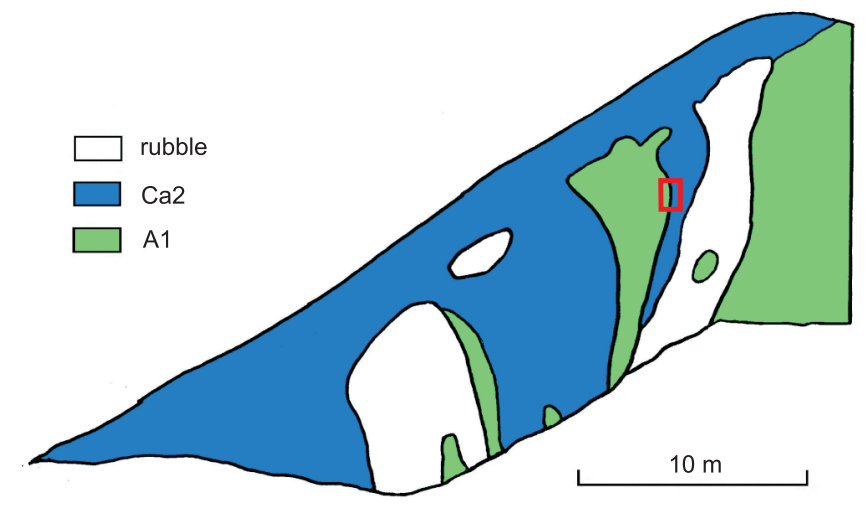

Fig. 13. Sketch-drawing of the central part of Figure 12

Red quadrangle shows position of Figure 14

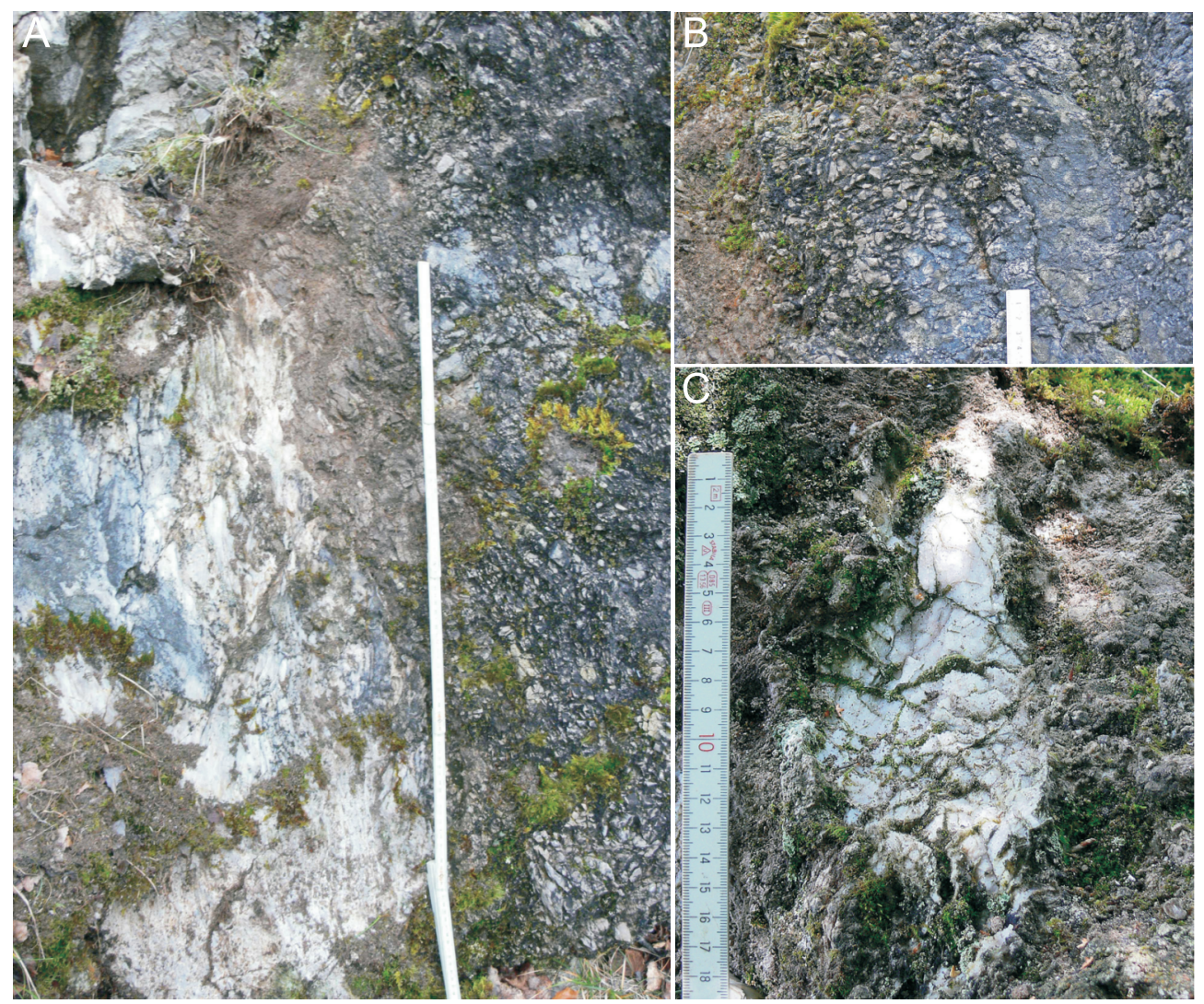

Fig. 14. Rötzel diapir

A - vertical contact of white gypsum (A1) on the left side and brecciated black and grey carbonate (Ca2) at the right side; the boundary between both rocks is jagged; grey spots within the gypsum consist of dolomite; the dolomite is completely brecciated (length of the rule - $1 \mathrm{~m}$ ); $\mathbf{B}$ - angular carbonate dolomite clasts without matrix (length of rule $-5 \mathrm{~cm}$ ); $\mathbf{C}$ - gypsum within the dolomite (Ca2), most likely, the fill of a cavity

In the case of A1 in Osterode and Nordhausen areas, the orientation of gypsum ridges is exactly parallel to the direction of Hercynian faults (like the Northern Harz fault). Most likely, these movements took place during the Cretaceous and later, but it seems that already during the Zechstein times a similar strain and stress field existed that was characteristic for later times. It is possible that small faults or irregularities of the overlying sediments triggered the rise of the gypsum and controlled the direction of the elongate ridges.

\section{AGE OF GYPSUM DIAPIRISM}

As previously mentioned, gypsum doming and diapirism began relatively early: in the case of $A 1$, before the overlying carbonates were completely lithified, and in the case of the A3, when the thickness of the overlying rock salt was less than $30 \mathrm{~m}$, as indicated by large anhydrite clasts within the salt bed (Fig. 1). The overlying Stassfurt Carbonate in the Hellenberg Quarry was not yet completely lithified when gypsum doming took place, but in the Rötzel Quarry, the already hard, lithified dolomite is broken 


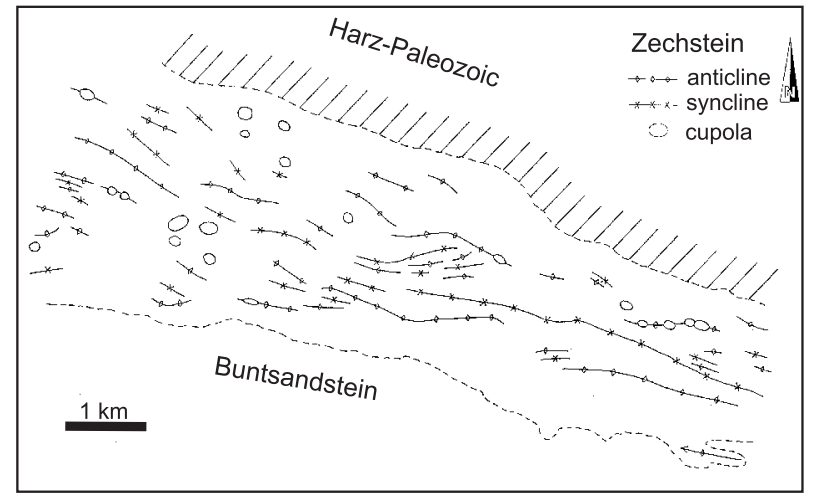

Fig. 15. Map of gypsum cupolas, anticlines and synclines in the area north of Nordhausen

Zechstein strata are cropping out, mainly Werra Anhydrite and Stassfurt Carbonate, between the Variscan Paleozoic rocks of the Harz Mts. and the Lower Triassic Buntsandstein

into small angular clasts near the gypsum diapir. This difference may depend on the nature of carbonates: thin-bedded clay-like dolomudstones are pliable, whereas thick-bedded pure dolowackestones are more brittle. In addition, the processes of lithification and dolomitization are slowed down by thin clay layers.

Hemmann (1972) and Schachl (1991) described, from several localities, large anhydrite blocks or clasts near the anhydrite domes within the Leine Salt (Na3). This is an indication of a very early uplift of the gypsum during the precipitation of the rock salt. Therefore, gypsum diapirism started very early, before the overburden necessary for the conversion of gypsum to anhydrite was reached or the depth at which the conversion occurred was smaller than previously assumed.

The duration of uplift is not known, but it was terminated by the conversion of gypsum to anhydrite. In A3, the growth of the diapirs stopped at the so-called "Anhydritmittel" (am1), an alternation of anhydrite and salt layers. It is assumed that the growth was terminated when equilibrium between the hydrostatic pressure and the pressure of the lithostatic overburden was reached.

\section{REASONS FOR GYPSUM UPLIFT}

The uplift of gypsum compared to rock salt or carbonates may have had several reasons:

- a high content of pore water in the sediment led to lower densities of the gypsum mud than of semi-lithified carbonates or rock salt;

- compaction and dewatering brought additional amounts of water below impermeable screening rock salt or carbonates (mudstones and wackestones);
- conversion of gypsum to anhydrite which started in the lower parts of gypsum beds brought additional water to the upper parts.

Due to the conversion of gypsum to anhydrite the volume of both water and anhydrite was increased by about $10 \%$ (Langbein, 1987). If the overlying strata hinders or prevents the escape of water, the hydrostatic pressure rises. Finally, gypsum and water lift up its roof or, if there are joints, penetrate the overlying strata.

In any case, the buoyancy was so great that the gypsum mud ascended at least $50 \mathrm{~m}$. The uplift stopped when the potential was exhausted, or when the gypsum mud had the same density as the host rock, or if most of the pore water had escaped by imperfect sealing horizons.

\section{CONCLUSIONS}

Gypsum domes and diapirs are known from three Zechstein sulphate units around the Harz Mts. It is a common feature and is independent of salt diapirism. The uplift of the gypsum started very early before the conversion to anhydrite took place and before the overlying carbonate beds were completely lithified and when the overlying sediments were only several tens of centimetres thick. Only the upper layers of the gypsum bed were involved in the movements. These layers reacted like gypsum mud and had, most likely, another composition (less carbonate content), structure (lack of selenite horizons) and/or higher content of pore water than the rest. The conversion of gypsum to anhydrite brought additional water into the system, increased the hydrostatic pressure and favoured the uplift of the gypsum.

Until now, the domes and diapirs of Zechstein sulphate horizons have been only observed from areas around the Harz Mts. In this area there are excellent conditions to investigate Zechstein evaporites. For 200 years salt was mined and at the surface there are several quarries of Zechstein sulphates, and the Harz region is the best-investigated area in the Zechstein Basin. There is no reason to assume that gypsum domes and diapirs are restricted to the Harz Mts.; instead it is highly probable that they occur in many areas of the Zechstein Basin.

Acknowledgements. Many thanks are due to M. Brandt, manager of gypsum quarry Schimpf (VG-Vorth $\mathrm{GmbH}$ \& Co.KG), who during the years made possible frequent excursions and visits to the quarries. Till Paul helped to produce digital drawings and made some photos. The original manuscript was reviewed by Dr. S. Burliga and Professor F. Orti who gave valuable critics, remarks and suggestions for improvement.

\section{REFERENCES}

Behr, E.M., 1960. Geologische Beobachtung am Hauptanhydrit des Staßfurt-Egelner Sattels im Bereich des Kaliwerkes Staßfurt Schacht VI/VII. Freiberger Forschungshefte, C 90: 88-105.

Borchert, H., 1959. Ozeane Salzlagerstätten. Bornträger, Berlin.

Borchert, H., Baier, E., 1953. Zur Metamorphose ozeaner Gipsablagerungen. Neues Jahrbuch für Mineralogie, Abhandlungen, B 86: $103-154$.

Braitsch, O., 1962. Entstehung und Stoffbestand der Salzlagerstätten. Springer, Heidelberg.
Calaforra, J.M., Pulido-Bosch, A., 1999. Gypsum karst features as evidence of diapiric processes in the Betic Cordillera, Southern Spain. Geomorphology, 29: 251-264.

Denison, R.E., Peryt, T.M., 2009. Strontium isotopes in the Zechstein (Upper Permian) anhydrites of Poland: evidence of varied meteoric contributions to marine brines. Geological Quarterly, 53 (2): 159-166.

Everding, H., 1907. Zur Geologie der deutschen Zechsteinsalze. In: Festschrift zum X. Allgemeinen Bergmannstag Eisenach (ed. F. 
Beyschlag): 25-133. Königlich preußisches geologisches Landesamt, Berlin.

Finkenwirth, A., 1982. Die Gipslagerstätte der Grube Pöhlen in der Randfazies des Zechstein 1 bei Diemelsee-Adorf/Ostsauerland. Unpublished diploma thesis. University Clausthal.

Fleischer, S., 1960. Die stratigraphische, fazielle und tektonische Ausbildung des Hauptanhydrits auf dem Berlepsch-MaybachSchacht in Staßfurt. Freiberger Forschungshefte, C90: 52-87.

Fulda, E., 1929. Über „Anhydrit-Klippen“. Kali, 23: 129-133.

Hardie, L.A., 1967. The gypsum-anhydrite equilibrium at one atmosphere pressure. American Mineralogist, 52: 171-200.

Hemmann, M., 1968. Zechsteinzeitliche Gips/Anhydrit Umwandlung, Anhydritklippenbildung und zugehörige Erscheinungen in der subherzynen Leine-Serie. Mineralogie. Deutsche Akademie der Wissenschaften, 10: 454-462.

Hemmann, M., 1972. Ausbildung und Genese des Leinesteinsalzes und des Hauptanhydrits (Zechstein 3) im Ostteil des Subherzynen Beckens. Berichte der Deutschen Gesellschaft für geologische Wissenschaften, B16: 307-411.

Herrmann, A., 1957. Der Zechstein am südwestlichen Harzrand. Geologisches Jahrbuch, 72: 1-72.

Herrmann, A., Richter-Bernburg, G., 1955. Frühdiagenetische Störungen der Schichtung und Lagerung im Werra-Anhydrit (Zechstein 1) am Südwestharz. Zeitschrift der Deutschen Geologischen Gesellschaft, 105: 589-702.

Jung, W., Gerlach, R., Knitzschke, G., 1969. Zur Feingliederung des Hauptanhydrits (A3) im zentralen Zechsteinbecken. Geologie, 18: 1164-1172

Kosmahl, W., 1967. Grauer Salzton und Hauptanhydrit des Zechsteins in Nordwestdeutschland. Geologisches Jahrbuch, 84: 367-406.

Kosmahl, W., 1969. Zur Stratigraphie, Petrographie, Genese und Sedimentation des gebänderten Anhydrits (Zechstein 2), Grauen Salztones und Hauptanhydrits (Zechstein 3) in Nordwestdeutschland. Geologisches Jahrbuch, Beiheft, 71: 1-129.

Kulick, J., 1987. Zechstein am Westrand der Hessischen Senke. In: Zechstein 87 (eds. J. Kulick and J. Paul). Internationales Symposium. Exkursionsführer, 2: 39-80, Wiesbaden.

Langbein, R., 1968. Zur Petrologie des Anhydrits. Chemie der Erde, 27: 1-38.

Langbein, R., 1987. The Zechstein sulphates: the state of the art. Lecture Notes in Earth Sciences, 10: 143-188.

Langbein, R., Peter, H., Schwahn, H-J., 1982. Karbonat- und Sulfatgesteine. VEB Deutscher Verlag Grundstoffindustrie, Leipzig

Lotze, F., 1938. Steinsalz und Kalisalze - Geologie. In: Die wichtigsten Lagerstätten der Nicht-Erze. III, part 1 (ed. O. Stutzer). Bornträger, Berlin.

Lotze, F., 1957. Steinsalz und Kalisalz, Gebrüder Borntraeger, Berlin.

Marsal, D., 1952. Der Einfluß des Druckes auf das System $\mathrm{CaSO}_{4}-\mathrm{H}_{2} \mathrm{O}$. Heidelberger Beiträge zur Mineralogie und Petrographie, 3: 289-296.

Paul, J., 1987. Der Zechstein am Harzrand: Querprofil über eine permische Schwelle. In: In: Zechstein 87 (eds. J. Kulick and J. Paul). Internationales Symposium. Exkursionsführer, 2: 193-276, Wiesbaden.

Paul, J., 1993. Anatomie und Entwicklung eines permo-triassischen Hochgebietes: die Eichsfeld-Altmark-Schwelle. Geologisches Jahrbuch, A131: 197-218.
Paul, J., Quast, A., Ahlborn, F., Plache, M., Reh, R., 1998. Geologie des Gipskarstgebietes zwischen Nordhausen und Stempeda (Zechstein, südlicher Harzrand). Geowissenschaftliche Mitteilungen von Thüringen, 6: 57-81.

Peryt, T.M., 1994. The anatomy of a sulphate platform and adjacent basin system in the Łeba sub-basin of the Lower Werra Anhydrite (Zechstein, Upper Permian), northern Poland. Sedimentology, 41: 83-113.

Peryt, T.M., Geluk, M., Mathiesen, A., Paul, J., Smith, K., 2010a. Zechstein. In: Petroleum Geological Atlas of the Southern Permian Basin Area (eds. J.C. Doornenbal and A. Stevenson): 123-147. EAGE Publications, b.v. (Houten).

Peryt, T.M., Hałas, S., Hryniv, S.P., 2010b. Sulphur and oxygen isotope signatures of late Permian Zechstein anhydrites, West Poland: seawater evolution and diagenetic constraints. Geological Quarterly, 54 (4): 387-400.

Reimann, M., 1991. Zur Vergipsung der Zechsteinanhydrite Nordwestdeutschlands. Zentralblatt für Geologie und Paläontologie, I: 1201-1210.

Reimann, M., Richter, M., 1991. Lithological sequence of the Main Anhydrite (Zechstein 3) in the Piła IG1 borehole (Poland) in comparison with the normal sequence in the Hannover area (NW Germany). Przegląd Geologiczny, 39: 203-206.

Renner, O., 1914. Salzlager und Gebirgsbau im Mittleren Leinetal. Archiv für Lagerstättenforschung, 13.

Richter, G., 1934. Hauptanhydrit und Salzfaltung. Kali, 28: 93-95, 105-107, 122-124.

Richter-Bernburg, G., 1955. Stratigraphische Gliederung des deutschen Zechsteins. Zeitschrift der Deutschen Geologischen Gesellschaft, 105: 843-854.

Richter-Bernburg, G., 1985. Zechstein-Anhydrite - Fazies und Diagenese. Geologisches Jahrbuch, A85.

Schachl, E., 1954. Das Muschelkalksalz in Südwestdeutschland. Neues Jahrbuch Geologie und Paläontologie, Abhandlungen, (1954): 309-394.

Schachl, E., 1991. Das Steinsalzbergwerk Braunschweig-Lüneburg, Schichtlagerung in der Wurzelzone eines Salzstocks. Zentralblatt für Geologie und Paläontologie, I: 1223-1245

Seidl, E., 1914. Die permische Salzlagerstätte im Graf-MoltkeSchacht und in der Umgebung von Schönebeck a. d. Elbe. Archiv für Lagerstättenforschung, 10.

Struensee, G. von, 1981. Zechstein. In: Erläuterungen zur Geologischen Karte 1:25 000, Blatt 3327 Lindwedel (ed. H.-D. Lang): 10-18. Hannover

Warren, J.K., 1999. Evaporites. Their Evolution and Economics. Blackwell, Oxford.

Weber, K., 1931. Geologisch-petrographische Untersuchungen im Staßfurt-Egelner Sattel unter besonderer Berücksichtigung der Genese der Polyhalit- und Kieserit-Region. Kali, 25: 17-23, 49-55, 82-87, 97-104.

Williams-Stroud, S., Paul, J., 1997. Initiation and growth of gypsum piercement structures in the Zechstein Basin. Journal of Structural Geology, 19: 897-907.

Zwanzig, W., 1928. Die Zechsteinsalzlagerstätte im oberen Allertale bei Wefensleben-Helsdorf. Kali, 22: 45-49, 62-66, 76-79, 92-94, 113-116. 